\title{
Thoughts on ENGINEERING ETHICS EdUCATION IN CANADA
}

\author{
Andrew Roncin, P. Eng. \\ Red River College \\ aroncin@rrc.ca
}

\begin{abstract}
The purpose of this paper is to summarize current research in engineering ethics education and interpret it within the Canadian engineering and accreditation context.

Outcome 3.1.10 of the Canadian Engineering Accreditation Board is that upon graduation students have an "ability to apply professional ethics, accountability, and equity". Yet teaching students to memorize a few canons and acts does little to help them recognize and resolve ethical conflicts effectively. The ability to apply their knowledge implies that students have had practice recognize ethical conflicts, interpret the positions of stakeholders, and designing solutions that address the myriad of ethical viewpoints that stakeholders may have.

Our engineering acts, bylaws, and codes of conduct affirm that Engineering is about more than just crunching numbers, it is about serving the needs of society and creating solutions that work. In order to learn this, young engineers need opportunities to experience, explore, and resolve ethical dilemmas and in doing so develop a deeper understanding of the impact of engineering on society.
\end{abstract}

Keywords: Engineering Ethics, Professional Ethics, Andragogy, Canada, CEAB

\section{INTRODUCTION}

Engineering is full of ethical decisions. By the nature of our profession, we design, build, and create technologies that disrupt the status quo, enable new ways of behaving, and have unknown consequences on the world [1] [2] [3]. And a core element of the engineering design process is making tradeoffs about materials, costs, and processes. Tradeoffs guided as much by budgets and physical constraints as own sense of morality and professional ethics. Engineering decisions are not value neutral, rather they are value laden [2]. What we believe is right and wrong and what we believe to be professional behavior has an impact on the world around us.

\section{THE IMPORTANCE OF ENGINEERING ETHICS}

By its nature, engineering is the act of creating artifacts that enhance the human experience by changing, modifying, and controlling the world around us. Whether we are creating safe drinking water, developing more efficient machines through composite materials, or enabling a wired world through embedded systems engineering is not without cost and consequence.

In creating safe drinking water, we change the demographics of a region. Encouraging people to move to the area and thereby increasing its population density and associate pollution problems.

In optimizing an engine or machine through specialized composite materials, we create artifacts that are harder to recycle and which may cause serious health problems in the future.

And while satisfying our need for communication and data systems, we contribute to the proliferation of e-waste and heavy metals in our environment.

Engineering is not without cost and consequence rather it is about minimizing them. It is about more than just calculating the optimal solution - it is also about understanding the impact our work has on the world around us.

And it is because of this impact that we need to give our young engineers an appreciation for the complexities of design and operating in the real world [4] [5] [6] [7]. Complexities which require engineers to think about the costs, the benefits, and the impact of designs have over their whole lifecycle.

In the words of D.H Long, "Engineering competence does not ensure moral goodness, nor does moral goodness guarantee engineering competence. Both are necessary; neither is sufficient. [8, p. 353] 


\section{A QUESTION OF PROFESSIONAL ETHICS}

Outcome 3.1 .10 of the Canadian Engineering Accreditation Board [9, p. 14] is that upon graduation, students have "an ability to apply professional ethics, accountability, and equity". But what are "professional ethics" and how do we teach them?

\subsection{Philosophical and applied ethics}

Before examining the question of professional ethics, an important distinction needs to be made here between philosophical and applied ethics [10].

Philosophical ethics is the study of right and wrong with the intent of creating universal models and ethical theories by analyzing decisions that have been made.

Whereas applied ethics are about determining the right course of action to take. Applied ethics is about balancing the different models of right and wrong, understanding the social and ethical standpoints of the stakeholders involved, and choosing right course of action.

Professional ethics and more specifically engineering ethics are subsets of applied ethics.

\subsection{Professional and Engineering Ethics}

At its core, professional ethics mean the professional responsibilities that members of a profession have to society because of their specialized knowledge [4] [11] [7]. Engineering ethics are the same as professional ethics with the scope explicitly tied to the engineering profession.

Engineering ethics are generally interpreted in one of three ways:

(1) Understanding the codes of conduct that apply to members of the engineering profession [4].

(2) Training engineers to recognize moral issues in their workplace and to give them philosophical models by which to evaluate their decisions [10] [12].

(3) As having engineering students look at the social morality of individuals and corporations involved in engineering [2] [7] [13].

\subsection{Codes of Conduct}

Standalone courses in professional ethics, often focus on the codes of conduct, protecting the public, conflict of interest, duty to inform, and the requirement for technical competence [7] [14] [15] [16]. In this environment, students are indoctrinated into the special codes of conduct that are expected of engineers, because of their profession. This training in the fundamentals of engineering is critical because "except for those students lucky enough to have a mother or gather who is an engineer, no one is likely to learn much about engineering ethics except at engineering school or while practicing engineering" [4, p. 93].

Unfortunately, students are in the environment of time constraints and right answers. Where what truly matters to them is a GPA and knowing how to pass the next test. The burning question in their minds is: "What do I need for the exam?"

It is not to say that teaching the dogma of engineering is not important. Rather, it is to emphasize that students are focused on marks and ultimately a job. If they cannot see immediate benefit and cash value in a course, then they will resist it.

\subsection{Moral Judgement}

In the 1980's the Hastings Center released a report outlining the underlying objectives of ethics education [4] [17] [18]. Proponents of teaching philosophical ethics within engineering often cite these objectives as justification for analyzing case studies and introducing ethical models. The five Hastings Center objectives of ethics education are: (1) stimulate ethical thinking, (2) recognize ethical issues, (3) analyze ethical concepts, (4) develop responsibility (5) deal with ethical ambiguity [4] [17] [18].

By teaching philosophical ethics, it is hoped that engineering students will be more able to recognize moral issues and understand how their own ethical biases affect decisions. The three models of interest to engineers are Utilitarian, Deontology, and virtue ethics [10].

Utilitarianism looks at trying to maximize the greatest good, for the greatest number of people. This position appeals to engineers, because it appears value-neutral and facilitates cost vs. benefit analysis. It allows students to crunch the numbers and justify their solutions based on mathematical models. Unfortunately, Utilitarianism can be abused to favour the masses, or justify otherwise immoral decisions on the basis of cost.

With Deontology and Kantian ethics, one is concerned with creating equality through rules. The morality of which is assessed by answering the question, would you have the same rule applied to you? And although this may seem quaint, engineering is by and large a codified, rule based profession. A quick look at building codes or technical standards drives this point home.

And finally the least mentioned and perhaps most valuable model is virtue ethics. Which asks what would a virtuous engineer do in this case? Unfortunately, virtuous behaviour is largely subjective and hard to agree upon.

Engineers Canada has a code of ethics which is representative of its member organizations [19] and valuable in defining a virtuous engineer. By their code of ethics, a virtuous engineer (1) holds public safety paramount, (2) is technically competent, (3) is faithful to 
their employer, (4) informed, (5) conducts themselves in good faith, (6) advocates engineering judgement, (7) watch out for illegal or unethical engineering practices, (8) is socially and environmentally aware, and (9) equitable in their treatment of others. Essentially, a virtuous engineer is trustworthy, competent, and fair in their dealings.

When engineers demonstrate and apply these three characteristics; I believe most people would agree they are acting in a professional manner in line with the intent of the CEAB requirements.

The challenge here is that engineering students see philosophy as being separate from engineering. A fact exacerbated by the common choice to outsource ethics instruction to other departments [8] [13].

\subsection{Engineering Morality in Society}

To understand the relationship [7] [13] between society, technology, and the environment, students need to see their work in a broader scope and compare their understanding of professional responsibility against that of their peers [7] [18].

Because reciting codes and answering multiple choice tests do not build the moral character we expect of those in the engineering profession [17] [20] [21]. Rather, the required change comes from the students testing their intuition and judgement against their peers [18] and being forced into authentic learning environments [20] [22] [23] where they can analyze situations and articulate compelling arguments about the best course of action to take [13].

\section{METHODOLOGY}

Throughout the literature, case studies are held up as the method of choice for ethics instruction [7] [18]. Case studies offer students the opportunity for situated learning, to take on the role of a professional engineer -identifying ethical issues and coming up with creative solutions [18]. They also facilitate learning ethics by (1) allow students to take different roles in the case, (2) using narrative to make the stories more memorable, (3) hearing other perspectives and moral positions, and (4) providing an opportunity to build moral consensus [18].

However, because of time constraints, engineering educators often focus on case studies that featuring big media/bad [18] news cases that actually cause students to discount the failures as isolated incidences and further dissociate from the message by thinking they will not be working on major projects like the ones shown [7] [13] [23].

\section{VALIDATION}

Despite being required by $\mathrm{ABET}$ and $\mathrm{CEAB}$, the topic of validating learning in ethics education is surprisingly absent. Of all the papers reviewed, only [14] and [24] mention the topic.

In [14] Alfred and Chung question the validity of the current practice of teaching codes of ethics or using philosophical evaluation based cases education. Because students need to be "actors/agents rather than observers in the ethical situation"

Within their own work, they found that that following the NSPE's code of ethics hindered the results because it was a theoretical dogma which was not representative of real world practice.

In [24] Keefer, highlights how online ethics cases "have become more accessible and their use in SEE courses more frequent, there is little research available to indicate the effects of these materials on student learning". He further points out that the current models of validation are hampered student learning funnel students to a few ethical models or accepted outcomes. Thereby suppressing the very moral judgements that were initially sought.

Keefer also highlights how instructors looking to validate their teaching end up using the Defining Issues Test (D.I.T.) incorrectly, noting that the test was originally designed to evaluate which moral theories students were using and not to assess the development of ethical behavior.

In the end, the validation for teaching engineering ethics centers around the experiences gained by analyzing cases. Proponents identify success by stating that students begin to look for more creatively at the solutions to the problems and develop a consistency within the responses. And although the documentation may satisfy accreditation, one must stop and wonder if these experiences really mean that students can apply the concepts of professional (engineering) ethics in practice. Or if they are simply providing the answers their instructor is looking for.

\section{NORTH AMERICAN VARIATIONS}

\subsection{The Right to Title}

In Canada, the titles engineer, professional engineer, and P.Eng. are legally protected and tied registration in the provincial engineering regulatory body.

In the United States, the titles professional engineer and engineer are separate. Professional engineer implies registration with the National Society of Professional Engineers, whereas the title engineer is assigned by a company to engineering or technology graduates [15]. 
This distinction is important, because although much of the American literature is aimed at teaching engineering students, the separation between professional engineers and corporate titles was never made.

Furthermore, my impression was that the authors expected engineering students to work in a corporate setting where the ethics of the organization and contractual obligations trump the ethical expectations of being an engineer.

\subsection{Industrial Exemptions}

In Canada, Ontario is the only jurisdiction to have an industrial exemption and that is being repealed September 1, 2013. In Ontario, this exemption for tool and die makers means that machinery being designed and used in house only required an engineer to certify the safety and fitness aspects of equipment before it goes into service. In an effort to improve worker health and safety, the government of Ontario is repealing this law and now requiring that engineers be involved in the whole design process[25]. The rational being that engineers are held to a higher ethical standard, have more to lose, and therefore will be more attentive to the design.

In the United States, industrial exemptions are commonplace, and engineers are not required to take personal responsibility for the products they work on. Although a court may still find them negligent, responsibility for the designs is passed on to their employer.

In Canada, engineers are expected to seal plans, specifications, reports or documents being used by another party. In doing so, the engineer in question is taking on personal responsibility for the work.

\section{REFLECTION}

As my mother described it to me, "Ethics is what you do when no one else is looking". It's demonstrated through your values and actions. It's who you are.

Professional ethics are no different. They represent who you are as a professional. And in Canada, that means being competent, trustworthy, and treating others with fairness.

And as members of a self governing profession, cases of misconduct cause us collective shame. And leave us wondering - how could an engineer have done this?

Identifying what to teach is one challenge. Ethics instruction is plagued by a diversity of definitions and goals. Yet a bigger and more important question should be. How do we make the material real to our students so that they do not become the source of another big news/bad media case study?
We have a distinct advantage in Canada. Engineering schools are only the beginning of an engineer's career. Perhaps the best course of action is to teach the fundamental cannons in school, and then utilize courses during the Engineer - In - Training period to introduce the ethics and moral requirements of the engineering profession. Because in these first few years of their careers, our young engineers will truly see themselves as practitioners and will likely be faced with the very ethical challenges we hope for them to recognize and resolve.

\section{CONCLUSION}

Although it is expected behaviour, engineering ethics is not an easy topic to define. It has many different meanings, interpretations, and teaching outcomes. Yet the common thread is the responsibilities we take on by being engineers, whose specialized knowledge is important to society.

Today's engineers are expected to be more than technical experts; they are expected to be sage counsel and faithful agents to their employers. Advising them not only on how to solve problems in the most cost efficient manner, but also ensuring that the methods selected ensure public safety and minimize the environmental and societal consequences that ensue. Engineering is a morally and ethically entrenched profession. And teaching students to recognize the implications of their work and design solutions that minimize the negative impacts is by its nature, teaching them how to think like an engineer.

\section{References}

[1] J. F. Ahearne, "E3: Energy, Engineering, and Ethics," in Emerging Technologies and Ethical Issues in Engineering: Papers from a Workshop, Washington, The National Academies Press, 2004, pp. 67-76.

[2] C. E. Harris, "The Good Engineer: Giving Virtue its Due in Engineering Ethics," Science and Engineering Ethics, vol. 14, pp. 153-164, 2008.

[3] L. L. Bucciarelli, "Ethics and engineering education," European Journal of Engineering Education, vol. 33, no. 2, pp. 141-149, 2008.

[4] C. E. Harris, M. Davis, M. S. Pritchard and M. J. Rabins, "Engineering Ethics: What? Why? How? And When?," Journal of Engineering Education, pp. 93-96, 1996.

[5] C. J. Abate, "Should Engineering Ethics be Taught?," Science and Engineering Ethics, vol. 17, no. 3, pp. 583 596, 092011.

[6] T. Nathans-Kelly, S. Courter, K. Anderson, C. Nicometo and T. McGlamery, "In-Situ Ethics: the ethical sensibility that engineers bring to their work," in Proceedings of the 118th Annual American Society of Engineering Education 
(ASEE) , Louisville, KY, 2010.

[7] W. T. Lynch and R. Kline, "Engineering Practice and Engineering Ethics," Science, Technology \& Human Values, vol. 25, no. 2, pp. 195-225, 2000.

[8] J. Lincourt and R. Johnson, "Ethics Training: A Genuine Dilemma for Engineering Educators," Science and Engineering Ethics, vol. 10, no. 2, pp. 353-358, 2004.

[9] Engineers Canada, "Canadian Engineering Accreditation Board: Accreditation Criteria and Procedures," Canadian Council of Professional Engineers, Ottawa, 2012.

[10] I. Van de Poel and L. Royakkers, Ethics, Technology, and Engineering: An Introduction, Chichester, West Sussex: Wiley-Blackwell, 2011.

[11] J. Li and S. Fu, "A Systematic Approach to Engineering Ethics Education," Sci. Eng. Ethics, 23 November 2010.

[12] D. H. Long, A Guide to Teachers of Engineering Ethics, American Society of Mechanical Engineers, 2001.

[13] J. R. Herkert, "Engineering Ethics Education in the USA: Content, pedagogy and curriculum," European Journal of Engineering Education, vol. 25, no. 4, pp. 303-313, 2000.

[14] M. Alfred and C. Chung, "Design, Development, and Evaluation of a Second Generation Interactive Simulator for Engineering Ethics Education (SEEE2)," Science and Engineering Ethics, pp. 1-9, 02062011.

[15] M. (. Britton, Interviewee, Personal Communications. [Interview]. 2012.

[16] G. Hashemian and M. C. Loui, "Can Instruction in engineering Ethics Change Students' Feelings about Professional Responsibility?," Science and Engineering Ethics, vol. 16, pp. 201-215, 2010.
[17] K. M. T. Muskavitch, "Cases and Goals for Ethics Education," Science and Engineering Ethics, vol. 11, no. 3, 2005.

[18] C. Huff and W. Frey, "Moral Pedagogy and Practical Ethics," vol. 11, no. 3, pp. 389-408, 2005.

[19] Engineers Canada, "Guideline on the Code of Ethics," Engineers Canada, Ottawa, 2012.

[20] M. M. Lombardi, "Authentic Learning for the 21st Century: An Overview," Educause Learning Initiative, pp. 1-2, 2007.

[21] M. Davis and M. W. Keefer, "Getting Started: Helping a New Profession Develop an Ethics Program," Sci. Eng. Ethics, 17 March 2011.

[22] S. H. Unger, "Examples of Real World Engineering Ethics Problems," Science and Engineering Ethics, vol. 6, no. 3, pp. 423-430, 2000.

[23] T. P. Seager and E. Selinger, "Experiential Teaching Strategies for Ethical Reasoning Skills Relevant to Sustainability," in IEEE International Symposium on Sustainable Systems and Technology 2009, 2009.

[24] M. W. Keefer, "Making Good Use of Online Case Study Materials," Science and Engineering Ethics, vol. 11, no. 3, pp. 413-429, 2005.

[25] Professional Engineers Ontario, "Repeal of section 12(3)(a) of the Professional Engineers Act - Industrial," [Online]. Available:

http://www.peo.on.ca/index.php/ci_id/2259/la_id/1.htm. [Accessed 15 2013]. 